\title{
Methodological approaches to assessing food security of special consumers
}

\author{
Maxim Porvadov ${ }^{1}$, Liliya Akhmetshina ${ }^{2, *}$, and Larisa Vlasenko $^{3}$ \\ ${ }^{1}$ Military Academy Educational Institution of Logistics named after General of the Army \\ A.V. Khrulyov, 8, nab. Makarova, 199034, St. Petersburg, Russia \\ ${ }^{2}$ Financial University under the Government of the Russian Federation, 49, Leningradsky, 125993, \\ Moscow, Russia \\ ${ }^{3}$ Moscow State University of Civil Engineering, 26, Yaroslavskoye Shosse, 129377, Moscow, Russia
}

\begin{abstract}
Food supply for special consumers is the most dynamic subsystem of the system of procurement for power ministries and departments. In modern conditions, its functioning should take into account the peculiarities of the organizational structure of units and the nature of the tasks performed. The aim of the study is to systematize the existing methods for assessing the food security of the region and develop a methodological approach to assessing the food security of special consumers. As a result of the analysis of the existing methods for assessing the level of regional food security, conclusions were drawn about the absence of a single universal methodology for assessing food security, a variety of criteria and assessment indicators, the impossibility of unification, and comparative analysis by territories in accordance with their specificity and zoning. A conceptual diagram of an integrated assessment of the level of food security of special consumers is proposed.
\end{abstract}

\section{Introduction}

Assessment of the level of food security of power ministries and state departments (hereinafter referred to as special consumers) should be based primarily on the food supply system in the territories where the logistics centers of the relevant ministries and departments are located. Nowadays, in the scientific literature and practice, there are many indicators and criteria that are used to assess the level of food security of the territory where special consumers are located. However, there are no unified approach to assessing the food security of the region and a methodology for assessing the level of food security, in particular, for special consumers. This circumstance necessitates the development of a methodological approach to assessing the food security of special consumers and determines the relevance of the study.

\footnotetext{
* Corresponding author: akhmetshinalg@mail.ru
} 


\section{Materials and Methods}

The work was carried out on the basis of research materials by domestic authors on food security problems. As research methods, the study of various sources of information with the subsequent generalization of data, analytical and comparative methods were used.

Some authors assess food security through the prism of the effectiveness of the implemented agri-food policy, sustainable production of agri-food products, others believe to assess it as the level of self-sufficiency of the region with food of its own production.

Antamoshkina E.N. [1] proposes a model for the integrated assessment of the effectiveness of agri-food policy in the field of ensuring food security based on the definition of the effectiveness index (IaFP $I_{\text {eap }}$ - Effectiveness Index of Agrarian and Food Policy) in the form of aggregation of economic $\left(i_{e}\right)$, financial $\left(i_{f}\right)$ and social indicators $\left(i_{s}\right.$ )$:$

$$
I_{\text {eap }}=\sum\left(i_{e}+i_{f}+i_{s}\right)
$$

The author proposes to assess economic efficiency using the coefficient of actual food consumption $\left(K_{a c}\right)$, calculated as the ratio of the actual level of consumption $\left(q_{a c t}\right)$ and rational norms $\left(q_{\text {norm }}\right)$ :

$$
K_{a c}=\frac{q_{a c t}}{q_{\text {norm }}}
$$

The economic efficiency indicator is determined based on the ratio of actual food consumption:

$$
i_{e}=f\left(K_{a c}\right)
$$

The indicator of social efficiency is assessed using a set of three indicators: the share of the population with incomes below the subsistence minimum $\left(K_{p}\right)$; the share of food expenditures in the structure of household expenditures $\left(K_{c}\right)$; the degree of uneven distribution of the population by income $\left(K_{G I}\right)$ :

$$
i_{s}=f\left(K_{p} ; K_{c} ; K_{G I}\right)
$$

The indicator of financial efficiency is proposed to be assessed by calculating the level of food self-sufficiency $\left(K_{s}\right)$ :

$$
i_{f}=f\left(K_{s}\right)
$$

characterizing the completeness of food supply due to local production $(q)$ of the population $(n)$ in accordance with rational norms $\left(q_{r}\right)$ :

$$
K_{s}=\frac{q}{n \cdot q_{r}}
$$

At the same time, the author of this study proposes determining the level of efficiency of the agri-food policy (AP) in the following range of index values: 
1. $0<i_{\text {eap }} \leq 0.2-\mathrm{AP}$ is not effective;

2. $0.3<i_{\text {eap }} \leq 0.5-$ low level of AP efficiency;

3. $0.6<i_{\text {eap }} \leq 0.8-$ permissible AP level;

4. $0.9<i_{\text {eap }} \leq 1-$ optimal AP level.

In his dissertation work, Tryastsin M.M. proposes to assess the development of regional agri-food policy by means of the coefficient $\left(K_{d}\right)$ of the complex impact of allocated subsidies $(\Delta q)$ to cover the costs associated with price disparity ( $\Delta D)$, depreciation of funds $(\Delta Q)$ in the agro-industrial complex, inflation rates $(\Delta I)$, as well as food imports ( $\Delta \operatorname{Im})$.

$$
K_{d}=\frac{\Delta q}{\Delta D+\Delta Q+\Delta I+\Delta I m}
$$

The author determines the impact of sustainability of agricultural production on the food security of the region, which is calculated using statistical methods on the dynamics of productivity in crop production and productivity in animal husbandry [2, p.103-104].

Some authors assess the sustainability of agricultural production through the indicator of the sufficiency of agricultural raw materials to fulfill the function of satisfying the need for food, calculated by the generalizing criterion of the availability of raw materials:

$$
K_{o}=\left(\frac{R M}{P}\right)-1,
$$

where: $K_{o}$ - raw material supply criterion;

$R M$ - volume of agricultural raw materials produced;

$P$ - demand for raw materials by processing enterprises, $\mathrm{t}[3, \mathrm{p} .49]$.

Also, the impact of sustainable development of the agri-food system on food security is considered by A.A. Kazannikov through the prism of economic, social and environmental balance and their "equilibrium" state. In this case, the author presented the curve of the "equilibrium" state by the following formula.

$f(x)=$ Environmental damage $+[$ (High quality food products at optimal prices and low production costs) + Maximizing tax revenues] + Profit maximization for agricultural producers.

These parameters at a certain point on the curve will have a maximum value, and a certain point must be found at which the interests of each of the parties are maximized [4].

Z.M. Ilyina proposes to calculate stability of the agrarian sector by means of the coefficient of sustainability of production of raw materials and food ( $S_{i}$ ) according to the following formula:

$$
S_{i}=\left(\operatorname{Pr}_{\min _{i}} / \operatorname{Pr}_{c p_{i}}\right) \cdot 100 \%
$$

where $S_{i}$ - level of sustainability of production of the i-th type of food, \%;

$\operatorname{Pr}_{\text {min }_{i}}$ - the minimum volume of production of the i-th type of food in the region, thousand tons; 
$\mathrm{Pr}_{a v_{i}}$ - average volume of production of the $\mathrm{i}$-th type of food in the region, thousand tons.

At the same time, the author proposes to determine the potential for a shortage of the most important types of agri-food products in the region caused by the instability of production $\left(P_{i}\right)$ over a long period using the formula:

$$
P_{i}=\left(\left(\operatorname{Pr}_{\min _{i}}-\operatorname{Pr}_{c r_{i}}\right) / \operatorname{Pr}_{c r_{i}}\right) \cdot 100 \%
$$

where $P_{i}$ - the level of potential deficit of the i-th type of food in the region;

$\operatorname{Pr}_{c r_{i}}$ - critical volume of the region's demand for food of the i-th type, thousand tons [5].

Some authors propose to define the sustainability of agricultural production as a constantly maintained proportionality of needs and resources, then $S_{C}^{T}=1$, i.e. the sum of deviations of resources from needs will tend to zero.

In this case, resistance is calculated using the following formula:

$$
S_{C}^{T}=1-\left[\sum_{t=1}^{T}\left(N_{i}-R_{i}\right] / \sum_{t=1}^{T} N_{i} \quad(i=1,2,3 \ldots T)\right.
$$

where: $N_{i}$ - needs;

$R_{i}$ - resources.

Thus, the level of sustainability will be higher the less the deviation of the actual availability of resources from the standard value.

\section{Results}

Next, we will systematize the author's approaches to assessing the level of food security through the indicator of regional self-sufficiency for the main types of food.

Most scientists propose to calculate the coefficient of self-sufficiency of the region as the ratio of the volume of food consumption of its own production to the total volume of food consumption in the region.

T.F. Ryabovaya proposed to calculate the integral indicator of self-sufficiency in the main types of food $\left(I_{n}\right)$ :

$$
I_{n}=I_{M} \cdot I_{M L} \cdot I_{F} \cdot I_{V} \cdot I_{F} \cdot I_{P}
$$

where $n$ - the number of product types;

$I_{M}, I_{M L}, I_{F}, I_{V}, I_{F}, I_{P}$ - coefficients of self-sufficiency of the country in meat, milk, fish, vegetables, fruits, and potatoes, respectively [6].

In addition, it should be noted that on the basis of the indicator of regional selfsufficiency, it is possible to determine the specialization of regional agro-industrial production and the types of food required for import from other territories.

At the same time, regional self-sufficiency can lead to the isolation of regions from each other. The regions should be self-sufficient in certain types of food, depending on the territorial agricultural specialization, and the rest of the food products should be formed through import. Striving for full regional food self-sufficiency is not always advisable from 
the point of view of taking into account economic costs with a certain increase in food production.

Undoubtedly, high indicators of regional self-sufficiency reduce dependence on imported food supplies, with an increase in which there is an effect of a proportional reduction in the efficiency of regional agriculture.

Due to this, a number of authors distinguish such an indicator as the coefficient of coverage of food imports $\left(K_{F}\right)$ in the form of the ratio of the volume of exports of agrifood products to imports.

$$
K_{F}=\frac{V_{\text {exp }}}{V_{i m p}}
$$

where $V_{\exp }$ - food export volume;

$V_{\text {imp }}$ - food import volume.

It is noteworthy that in accordance with the Federal project "Export of agricultural products" [7], it is planned to increase the export of agricultural products to 45 billion US dollars in 2024. For this purpose, incentive programs for exporters have been developed in the country and the Russian Export Center operates (Table 1).

Table 1. Target indicators of the FI "Export of agricultural products", billion US dollars.

\begin{tabular}{|c|c|c|c|c|c|c|c|c|c|c|c|}
\hline \multirow[b]{2}{*}{ No } & \multirow{2}{*}{$\begin{array}{l}\text { Agricultural } \\
\text { products }\end{array}$} & \multirow{2}{*}{$\begin{array}{l}2017 \\
\text { (base) }\end{array}$} & \multicolumn{2}{|c|}{2018} & \multirow[b]{2}{*}{2019} & \multirow[b]{2}{*}{2020} & \multirow[b]{2}{*}{2021} & \multirow[b]{2}{*}{2022} & \multirow[b]{2}{*}{2023} & \multirow[b]{2}{*}{2024} & \multirow{2}{*}{$\begin{array}{c}2024 \\
\text { to } \\
2017 \\
\% \\
\end{array}$} \\
\hline & & & plan & fact & & & & & & & \\
\hline 1 & oil and fat & 3.1 & 3.6 & 3.2 & 4.0 & 4.4 & 5.0 & 6.7 & 7.6 & 8.6 & 277.4 \\
\hline 2 & cereals & 7.5 & 7.6 & 10.5 & 7.6 & 7.9 & 8.3 & 9.1 & 10.7 & 11.4 & 152.0 \\
\hline 3 & $\begin{array}{l}\text { fish and } \\
\text { seafood }\end{array}$ & 4.4 & 5.1 & 5.2 & 5.4 & 5.5 & 6.0 & 6.7 & 7.5 & 8.5 & 193.2 \\
\hline 4 & $\begin{array}{ll}\begin{array}{l}\text { meat } \\
\text { dairy }\end{array} & \text { and } \\
\end{array}$ & 0.6 & 0.9 & 0.7 & 1.1 & 1.3 & 1.6 & 2.0 & 2.5 & 2.8 & 466.7 \\
\hline 5 & $\begin{array}{l}\text { food and } \\
\text { processing } \\
\text { industry } \\
\text { products }\end{array}$ & 3.4 & 3.5 & 3.5 & 3.7 & 4.1 & 4.7 & 6.1 & 7.4 & 8.6 & 252.9 \\
\hline 6 & other & 2.5 & 2.2 & 2.8 & 2.1 & 1.8 & 2.4 & 3.4 & 5.3 & 5.2 & 208.0 \\
\hline & Total & 21.6 & 23 & 25.7 & 24 & 25 & 28 & 34 & 41 & 45 & 208.3 \\
\hline
\end{tabular}

Nowadays, food exports in value terms are slightly lower than imports, but this gap is gradually narrowing. Food export volumes are growing not only in value, but also in kind. At the end of 2018, shipments reached 77.9 million tons, which is $19.2 \%$ (12.6 million tons) more than a year earlier.

In recent years, the share of agricultural raw materials and foodstuffs in total export supplies has also been growing. So, in 2016-2018, it was in the range of 5.5-6.0\%, while back in 2001-2013 did not exceed 3.4\% (and in some years it was less than 2.0\%).

Exports of agricultural raw materials and foodstuffs from Russia in 2018 amounted to USD $24,884.9$ million, which is $20.2 \%$ (by USD 4,182.4 million) more than in 2017. Over 5 years versus 2013, supplies increased by $47.9 \%$ (by USD 8,058.9 million), over 10 years versus 2008 - increased by $169.0 \%$ (by USD 15,632.1 million), over 15 years (by 2003) increased by 7.9 times (USD 21,729.2 million).

It should be noted that the increase in export shipments within the framework of this federal project involves the modernization of the transport infrastructure of Russia. Until 2024, the following is envisaged: an increase in the throughput of transport routes (rail, road, water); construction and commissioning of 6 new export-oriented wholesale 
distribution centers (WDC); modernization of the port infrastructure (construction of grain and oil-loading terminals); organization of expedited route shipments of agricultural products to the PRC by rail (Agroexpress); acceleration and simplification of customs procedures for agricultural exporters.

Integration processes of domestic agri-food systems into world chains contribute to the development of the national agro-industrial complex. Nevertheless, one should not forget about the situation of "agri-food netback" or "export parity", according to which, when a certain type of food is imported, prices in the domestic market for the corresponding food become higher than world prices, which contributes to the formation of sufficiently comfortable conditions for domestic agricultural producers. But the situation can radically change if agricultural producers have export "surpluses". In this case, external export deliveries require conditions when domestic prices should "dive" under the world ones, since export products need to overcome logistical and technical barriers in importing countries. Since the "agri-food netback" is defined as the difference between the price of the benchmark (exchange quotation of the product) and the amount of transportation and customs costs required to deliver it to the buyer, as a result, the domestic agricultural producer will receive an additional market, but at the risk of margins.

Food independence can also be assessed using the coefficient of food dependence (authors Kravchenko A.A. and Khlystun A.Yu.):

$$
K=\frac{I}{P+I+E},
$$

where $I$ - food import volume,

$E$ - food export volume,

$P$ - the volume of own production of agri-food products.

The authors, in accordance with the proposed methodology, distinguish three levels of food dependence: a safe level of food dependence with a coefficient value of $0.1-0.2$; the threshold level is characterized by values of $0.21-0.49$; dangerous level - when the value of the coefficient of food dependence is above 0.5 [8].

According to the academician of the Russian Academy of Sciences I.G. Ushachev, the economic threshold is the share of imports at $20 \%$. Further, in his opinion, stagnation sets in and imports do not supplement, but suppress domestic agricultural production [9, p. 7].

According to T.M. Yarkova, national food independence is characterized by an indicator of no more than $25 \%$ of food imports, an alarming indicator of $30 \%$, and complete dependence on food imports with an indicator exceeding 50\% [10, p.118].

It should be noted that over the past five years, according to the Ministry of Agriculture of Russia, food imports decreased by $31.2 \%$ - from $\$ 43.3$ billion in 2013 to $\$ 29.8$ billion in 2018. The country achieved these indicators thanks to the implementation of the import substitution policy after the introduction of economic sanctions by Western countries in 2014 and counter-sanctions from Russia in the form of a food embargo. Nevertheless, in the overall structure of imports, agricultural raw materials and food still account for a significant share of $12.4 \%$ (Table 2) [11].

Table 2. Structure of Russian imports in 2019.

\begin{tabular}{|c|l|c|}
\hline No. & \multicolumn{1}{|c|}{ Name of imported products } & in \% \\
\hline 1 & Food products and agricultural raw materials & 12.4 \\
\hline 2 & Mineral products & 2.1 \\
\hline 3 & Chemical products & 18.3 \\
\hline 4 & Textiles and footwear & 6 \\
\hline 5 & Mechanical equipment & 18 \\
\hline 6 & Electrical equipment in quantity & 12.6 \\
\hline
\end{tabular}




\begin{tabular}{|c|l|c|}
\hline 7 & Cars & 3 \\
\hline 8 & Spare parts for vehicles & 0.8 \\
\hline 9 & Aircrafts & 2.7 \\
\hline 10 & Optical medical products and equipment & 2.8 \\
\hline 11 & Metals, incl. ferrous and non-ferrous metals & 7 \\
\hline 12 & Paper and cardboard & 1.1 \\
\hline
\end{tabular}

Despite this, at present, the country has not only reached, but also exceeded the threshold values of the food security doctrine for a number of key types of food. For example, the share of Russian foodstuffs in the total volume of resources of the domestic market at the end of 2018 was: for grain and leguminous crops - 99.4\%; sugar - 95.7\%; vegetable oil - 81.5\%; meat and meat products - 92.8\%; potatoes - 95\% [12].

N.I. Shagaida and V.Ya. Uzun propose to determine the general level of food independence (GLFI). [13, p.23]:

$$
G L F I=\left[\frac{1-(I-E)}{P S F}\right] \cdot 100
$$

where $I$ - food import cost;

$E$ - food export cost;

$P S F$ - the country's population spending on food.

In the Food Security Doctrine of the Russian Federation, food independence is defined as the level of self-sufficiency in percent, calculated as the ratio of the volume of domestic production of agricultural products, raw materials and foodstuffs to the volume of their domestic consumption.

The level of food independence $(F I)$ is calculated by the formula:

$$
F I=\left(\frac{A P}{V I P}\right) \cdot 100
$$

where $A P$ - agricultural production plus change in stocks (stocks at the beginning of the year minus at the end of the year);

$V I P$ - the volume of industrial and personal consumption of agricultural products.

It should be noted that in this formula, food export volumes are taken into account as part of the production indicator.

In the Ministry of Agriculture of Russia, the formula for calculating food independence looks similar, but instead of the indicator of the volume of production, the indicator of the volume of consumption of domestically produced products is used [13, p. 19]:

$$
F I=\left(\frac{V P_{c o n s}}{V I}\right) \cdot 100
$$

Thus, according to the methodology of the Ministry of Agriculture of Russia, the level of food independence cannot exceed $100 \%$, and exports are not taken into account in its calculation.

The approach that takes into account the import and export of food is presented by the methods of N.I. Shagayd and O.S. Sukharev [13, p.66; 14] and is calculated by the formula:

$$
P_{n}=\left[\frac{1-(I m-E x)}{R}\right] \cdot 100
$$

where Im , Ex - food imports and exports, respectively; 
$R$ - household spending on food.

Although these approaches are based on the priority of domestic food production, which is an integral part of food security, they do not allow taking into account the variety of criteria and indicators reflecting the availability of food, its affordability, quality and safety.

N.F. Kolodina [15] proposed a methodology for assessing food security by determining the sufficient amount of food by type of food $\left(V_{i}\right)$ :

$$
V_{i}=\sum V_{c}+V_{i}+V_{s s}
$$

where $V_{c}$ - the volume of domestic production of a certain type of food;

$V_{i}$ - the volume of imports of a certain type of food;

$V_{s s}$ - the volume of the safety stock of this type of food.

However, this methodology does not disclose such basic criteria of food security specified in the Doctrine, such as physical and economic accessibility, quality and safety of food.

The use of a complex integral indicator in assessing the food security of a region is reflected in the methodology of Yu.I. Terentyev. [16] and is proposed to be calculated as the sum of the coefficients of the diversity of food produced in the region; financial and quantitative availability of food for the population of the region; the volume of food imported into the region.

$$
K_{F S}=2+K_{D}-K_{F A}+K_{Q A}-K_{I}
$$

where $K_{D}$ - coefficient of diversity of food produced in the region;

$K_{F A}$ - coefficient of financial affordability of food for the population of the region;

$K_{Q A}$ - coefficient of quantitative availability of food for the population of the region;

$K_{I}$ - coefficient of the amount of food imported into the region.

In order to exclude negative values of this indicator, a free coefficient equal to 2 was introduced into the additive model by the author.

As the main disadvantages of the methodology for assessing regional food security proposed by Yu.I. Terentyev, it is necessary to highlight the lack of substantiation of the value of the free coefficient and the difficulty of obtaining initial information on a regional scale.

For a comprehensive assessment of the food security of the region, Mitrofanova I.V., Antamoshkina E.N. and Shlevkova T.V. propose to use a methodology based on the calculation of the scorecard:

1) food self-sufficiency ratio of the region $\left(K_{S}\right)$;

2) actual food consumption ratio $\left(K_{A C}\right)$ by main types of food;

3 ) indicators of affordability of food: poverty rate $\left(K_{P}\right)$; consumption rate $\left(K_{C}\right)$; Gini coefficient $\left(K_{G I}\right)$.

The range of threshold values of the calculated indicators is as follows: (acceptable - 1 point, optimal - 2 points, low or high - 0 points).

The food security index is determined using the following formula:

$$
I_{F S}=K_{S}+K_{A C}+K_{P}+K_{C}+K_{G I}
$$


In turn, the level of regional food security depends on the number of points.

With more than 9 points, the level is considered optimal, with 5-8 points - acceptable, and less than 5 points - low [17].

In our opinion, this methodology is not applicable to assess the food security of special consumers in terms of calculating indicators of the economic affordability of food, since the financing of the food supply system for special consumers comes from the federal budget.

No less interesting and applicable with some modification is the methodology for assessing the food security of the region presented by N.S. Dolgova [18]:

$$
L f s=(S b+P-P C-N F P-L o s-S e) / A N C
$$

where $L f S$ - level of food security;

$P$ - production volume for the period;

$S b$ and $S e$ - stocks at the beginning and end of the reporting period;

$P C$ - production consumption (as seeds, feed, and other purposes);

$N F P$ - processing on non-food purposes;

Los - losses;

$A N C$ - annual normative consumption calculated for the entire range of food products in the consumer basket of the minimum consumer budget of a man of working age as the product of the consumption rate per person per year by the average annual population of the region.

In the presented method, only one consumer group is taken into account, which does not allow taking into account the consumption of other groups in the population.

In this approach, it is necessary to calculate the annual standard consumption taking into account the consumption rates and the number of able-bodied adults, pensioners, children, and the personnel of special consumers deployed in a particular territory.

Despite the existing many points of view regarding approaches to assessing the level of food security in a region, the methodology for determining the level of food security of special consumers should be based on an integral approach to a set of indicators differentiated in accordance with generally accepted food security criteria.

\section{Conclusions}

The study of the existing methods for assessing food security allows drawing the following conclusions:

1. Lack of a single universal methodology for assessing food security, which makes it possible to conduct a comparative analysis by territories in accordance with their specificity and zoning;

2. Many different criteria and indicators of assessment;

3. Difference in comparability of indicators and criteria;

4. Lack of unification due to the variety of criteria and indicators, their heterogeneous dimension;

5. Lack of methodology for assessing the level of food security of special consumers.

Thus, it seems necessary to form a comprehensive methodology for the integral assessment of the level of food security of special consumers, taking into account the peculiarities of the agri-food specialization of the territories where special consumers are located, the stability of the territorial system of food supply and production of agri-food products, the transport and logistics infrastructure of the agri-food market, and the specifics of food provision for special consumers. At the same time, attention should be focused on the provision of domestically produced food. 
The proposed schematic diagram of an integrated assessment of the level of food security of special consumers should include the following stages:

1) selection of comparable criteria and assessment indicators;

2) reduction of indicators to one calculated dimension;

3) determination of the method for calculating each indicator;

4) calculation and analysis of the data obtained;

5) identification of potential threats to food security of special consumers;

6) development of options for increasing the level of food security of special consumers.

This approach will allow solving interrelated tactical and strategic tasks in the field of ensuring food security of special consumers in accordance with the main document defining these tasks and their ultimate goals - the Food Security Doctrine of the Russian Federation.

\section{References}

1. E.N. Antamoshkina, Food policy and security 3(3), 131-144 (2016)

2. M.M. Tryastsin, Management of sustainable development of the regional food market: dis. for the degree of Dr. of Econ. (Perm, 2009)

3. I.G. Kalkaev, Organizational and economic mechanism of sustainable development of the regional grain-product subcomplex (based on the materials of the enterprises of the agro-industrial complex of the Altai Territory): dis. for the degree of Ph.D. in Econ. (Novosibirsk, 2006)

4. A.A. Kazannikov, Vestnik of the Institute of Economics of the Russian Academy of Sciences 2, 87-94 (2015)

5. Z.M. Ilyina, Vestsi of the National Academy of Sciences of Belarus. Agrarian science series 2, 9-19 (2013)

6. T.F. Ryabova, Food industry, food security - XXI century: abstracts of the All-Russian scientific and practical conference (Yekaterinburg, Publishing House of the Ural State University of Economics, 1999)

7. Export of agricultural products. Federal project passport: Approved by the minutes of the meeting of the project committee of the national project "International cooperation and export" dated December 14, 2018 No. 5 (Information Telegraph Agency of Russia (ITAR-TASS), Information Portal "The Future of Russia, 2020) https://futurerussia.gov.ru/eksport-produkcii-apk

8. A.A. Kravchenko, A.Yu. Khlystun, Asia-Pacific region: Economics, politics, law 1, 24-36 (2010)

9. I.G. Ushachev, Vestnik of the Oryol State Agrarian University 5(14), 5-10 (2008)

10. T.M. Yarkova, Economic technologies for the formation and use of regional food stocks in the context of the WTO: dis. for the degree of Dr. of Econ. (Yekaterinburg, 2014)

11. Foreign trade in Russia, Statistics and indicators. Regional and federal (2020) https://rosinfostat.ru/vneshnyaya-torgovlya/

12. Over the past 5 years, Russia has reduced food imports by a third, Ministry of Agriculture of the Russian Federation (2019) https://mcx.gov.ru/press-service/news/zaposlednie-5-let-rossiya-sokratila-import-prodovolstviya-na-tret/

13. N.I. Shagaida, V.Ya. Uzun, Food security in Russia: monitoring, trends and threats (M., Publishing house "Delo" RANEPA, 2015) 
14. O.S. Sukharev, National interests: priorities and security 11.6(291), 44-53 (2015)

15. N.F. Kolodina, Vestnik of the Orenburg State University 13(188), 41-47 (2015)

16. Yu.I. Terentyev, Vestnik of Omsk University. Series: Economics 1, 43-46 (2004)

17. I.V. Mitrofanova, E.N. Antamoshkina, T.V. Shlevkova, Economy: yesterday, today, tomorrow 8(8C), 452-463 (2018)

18. N.S. Dolgova, Collection of reports of the I International Conference "Food Security of Russia" (Moscow, Rosinformagrotech, 2002)

19. L. Akhmetshina, T. Pokrovskaya, D. Semernin, MATEC Web of Conferences 193, 05047 (2018) https://doi.org/10.1051/matecconf/201819305047 